\title{
Just Transformations to Sustainability
}

\author{
Nathan J. Bennett ${ }^{1,2,3, *} \mathbb{C}^{-}$, Jessica Blythe ${ }^{4}{ }^{(}$, Andrés M. Cisneros-Montemayor ${ }^{1,5} \oplus^{(}$, \\ Gerald G. Singh ${ }^{1,5}$ and U. Rashid Sumaila ${ }^{1,6}$ \\ 1 Institute for the Oceans and Fisheries \& Institute for Resources, Environment and Sustainability, \\ University of British Columbia, Vancouver, BC V6T1Z4, Canada \\ 2 Center for Ocean Solutions, Stanford University, Stanford, CA 94305, USA \\ 3 ECOMERS, Université Côte d'Azur, CNRS, 06108 Nice, France \\ 4 Environmental Sustainability Research Centre, Brock University, St. Catharines, ON L2S3A1, Canada \\ 5 Nippon Foundation Nereus Program, University of British Columbia, Vancouver, BC V6T1Z4, Canada \\ 6 School of Public Policy and Global Affairs, University of British Columbia, Vancouver, BC V6T1Z2, Canada \\ * Correspondence: nathan.bennett@ubc.ca
}

Received: 29 May 2019; Accepted: 9 July 2019; Published: 17 July 2019

\begin{abstract}
Transformations towards sustainability are needed to address many of the earth's profound environmental and social challenges. Yet, actions taken to deliberately shift social-ecological systems towards more sustainable trajectories can have substantial social impacts and exclude people from decision-making processes. The concept of just transformations makes explicit a need to consider social justice in the process of shifting towards sustainability. In this paper, we draw on the transformations, just transitions, and social justice literature to advance a pragmatic framing of just transformations that includes recognitional, procedural and distributional considerations. Decision-making processes to guide just transformations need to consider these three factors before, during and after the transformation period. We offer practical and methodological guidance to help navigate just transformations in environmental management and sustainability policies and practice. The framing of just transformations put forward here might be used to inform decision making in numerous marine and terrestrial ecosystems, in rural and urban environments, and at various scales from local to global. We argue that sustainability transformations cannot be considered a success unless social justice is a central concern.
\end{abstract}

Keywords: Just transformations; social justice; environmental sustainability; transformations; sustainable development; environmental governance; social-ecological systems

\section{Introduction}

Many of the world's ecosystems are unsustainable at current levels of human use [1-5]. If left unchecked, environmental declines and degradation can undermine both environmental productivity and human health and well-being. Thus, ensuring the well-being of current and future generations within the limits of a finite planet is one of the defining challenges of our time. In response to this challenge, the notion of transformations towards sustainability has risen to the forefront of global scientific and policy endeavors. For example, international sustainability initiatives, including Future Earth [6], the Intergovernmental Science-Policy Platform on Biodiversity and Ecosystem Services (IPBES) [4,7] and the United Nations' 2030 Agenda for Sustainable Development [8], explicitly seek to understand and support deliberate societal transformations. On the ground, there is also a recognized need to radically transform the way we manage numerous marine, freshwater and terrestrial systems in rural and urban environments to promote environmental sustainability. Deliberate actions taken to achieve environmental sustainability might take many forms, from strict preservation where human 
use is curtailed to management actions that encourage more sustainable practices or reduce harvesting levels to environmental restoration or 're-wilding' activities [9].

When deliberate transformations to environmental sustainability are enacted, there will inevitably be social consequences both positive and negative relative to the status quo. Though there is the potential for improvements in human well-being, there is also a real danger that deliberate sustainability transformations will occur in an exclusionary manner or produce inequitable outcomes across time and space [10]. For example, fisheries management actions, such as the creation of no-take marine protected areas or reductions in fishing effort, can require short-term losses to produce long-term net economic gains [11]. However, even improvements in the aggregate benefits of environmental management alone may also not be enough to produce improvements in human well-being for all groups [12-16]. Furthermore, there have been significant critiques of the social justice implications of conservation and management efforts that aim to achieve environmental sustainability [17-20]. Many environmental sustainability decisions are made without adequate consideration of the rights, responsibilities, needs or perspectives of local people or processes to enable their participation [21-24]. Lack of consideration of local people's needs and voice can also undermine support of constituents and produce opposition, potentially undermining the long-term biological success of sustainability initiatives $[25,26]$.

We contend that the social justice implications of sustainability transformations require greater attention and suggest that the notion of 'just transformations' to sustainability can fill this space. In general, there is often limited engagement with social justice in broader sustainability science and practice. Furthermore, the emerging scholarship on deliberate transformations to sustainability has only just begun to engage with themes of social justice [27-29]. From our perspective, then, the uptake and application of the just transformations concept to environmental decision making requires that further attention be paid to how justice is conceptualized, how it might be operationalized during planning and management of sustainability transformations, and how research can support these efforts. To address these gaps and promote greater engagement, this conceptual and methodological paper reviews the literature on sustainability transformations, just transitions and social justice to characterize just transformations and offer practical and methodological guidance on considerations that might be used to help facilitate just transformations. In doing so, we aim to bring recognitional, procedural, and distributional justice to the forefront of emerging sustainability and transformations discourse, policies and practice. In conclusion, we examine how this thinking might be applied to a case study and discuss the challenges of navigating just transformations to sustainability.

\section{Literature Review: From Deliberate Transformations to Social Justice}

\subsection{Deliberate Transformations to Sustainability}

The notion of transformation is increasingly promoted in scientific and popular discourse as a solution to unsustainable practices [30,31]. Deliberate transformation conveys something more substantial or radical than incremental change [32]. While "incremental" changes may rely on current modes of thinking and governance structures to modify social-ecological systems (e.g., changes to existing taxation or fines for polluting industries), "radical" change may require deep systemic and structural shifts that challenges our assumptions, beliefs, and values, along with government regimes, development paradigms, and power relations (e.g., moving away from government imposed protected areas to community-based management [22]). The Intergovernmental Panel on Climate Change (IPCC) Special Report on Extreme Events defines transformation as "the altering of fundamental attributes of a system (including value systems; regulatory, legislative, or bureaucratic regimes; financial institutions; and technological or biological systems)" [33] (p. 3). A transformative response to climate change implies that limiting global climate change to $1.5^{\circ} \mathrm{C}$ will require engaging with the root causes of inequality and environmental degradation, as opposed to simply pricing carbon or investing in renewables [27,34]. The IPBES recently released a summary report that calls for transformative changes to society, stating "Goals for conserving and sustainably using nature and achieving sustainability 
... .may only be achieved through transformative changes across economic, social, political and technological factors" [4].

While still a nascent field, the scholarship on transformations to sustainability has been informed by three distinct literatures that offer important insights. First, the transition literature emphasizes the role of socio-technological innovations in catalyzing transformations towards low carbon futures in sectors such as transportation, agriculture and energy $[35,36]$. Research on socio-technical transitions has sought to understand how to accelerate long-term structural transitions through leveraging change at three levels: niche (i.e., technological innovations), regime (i.e., the socio-technical system), and landscape [37]. Though it emerged from somewhat different theoretical and academic origins, the transitions literature has informed transformations thinking regarding how to leverage change in systems in a stepwise manner [38-42]. Second, the transformational adaptation literature distinguishes between incremental adjustments and transformational responses [30]. This perspective emphasizes the importance of contesting dominant social and political structures, rather than accommodating change, to address the root causes of unsustainable systems and catalyze genuinely alternative futures [34]. This explicitly political perspective argues that market-based approaches or technological innovations are, in many instances, insufficient to produce sustainability transformations [43]. Third, the resilience literature conceptualizes transformations as triggered by crises, or abrupt non-linear change, in linked social-ecological systems [44-46]. Here transformations are understood to result in new regimes, defined by novel system properties and feedbacks between social and ecological components of the system $[47,48]$. Resilience thinkers have also collaborated with scholars from other fields to propose theoretical approaches for characterizing and navigating transformations, including transformational adaptation [49] and sustainability pathways [50,51].

\subsection{Transformations and Justice}

Transition scholars, in particular, have more explicitly engaged with themes of social justice. While early thinking on socio-technical transitions was criticized for underplaying the role of justice [52,53], more recent writing has paid closer attention to distributive processes involved in societal change. For example, Swilling et al. [54] (p. 650) explore the possibility for a 'just transition' in South Africa, which they conceive of as "a dual commitment to human well-being (with respect to income, education and health) and sustainability (with respect to decarbonization, resource efficiency and ecosystem restoration)". Through their analysis of the politics of energy transitions, Newell and Mulvaney [55] (p. 132) conclude that "issues of equity and justice will be intrinsic to whichever energy trajectory is pursued". This thinking on 'just transitions' has been informed by strands of literature on environmental and climate justice [56-62]. However, the notion of 'just transitions' has focused almost exclusively on the energy sector. While renewable energy transitions are an essential component of sustainable futures, transformations across multiple sectors and human activities are required if humanity is to live sustainably [63]. Indeed, "affordable and clean energy" (Sustainable Development Goal 7) is but one of seventeen areas understood to be critical for realizing the 2030 Agenda for Sustainable Development [8].

Perhaps because the scholarship on transitions and transformations have emerged somewhat separately $[38,64]$, engagement with themes of social justice has largely remained confined to the transitions literature. Within the research on transformations to sustainability, little emphasis has been placed on the differentiated social impacts of such profound change or the level of inclusion of implicated actors in decision making [53]. For example, the word 'justice' is only used once in Karen O'Brien's [30] seminal paper on deliberate transformations and there is no mention of 'justice' on Future Earth's description of their transformation program [6]. Yet, we know that societal transformations at any scale are shaped by, and will shape, the distribution of wealth, opportunities, and privileges afforded to different social groups [10]. While notions of justice have recently started to permeate writing on transformations to sustainability [27-29], more attention is needed to both understanding and realizing social justice during sustainability transformations. 


\subsection{Conceptualizing Social (In) Justice}

Past research has documented a number of the potential risks of sustainability practices from a social justice perspective. Potential social injustices have included: (a) lack of the recognition of pre-existing rights, needs and livelihoods of distinct stakeholders [65-67]; (b) exclusionary decision-making process that fail to include local people $[26,68,69]$; (c) negative social consequences of management actions that undermine human-well-being [70-72]; (d) unequal distribution of costs and benefits to different groups [73-75], and (e) elite capture of the long-term benefits, thus increasing social inequity during and after a transformation [76-79]. Recognizing that any sustainability initiative has the potential to be done in an exclusionary or inclusive fashion and to increase or decrease social justice, we argue that strategic thinking and planning is needed to manage deliberate transformations in a manner that is just. As shown in Figure 1, this implies addressing existing—though potentially avoidable—-tradeoffs in policies that seek to co-achieve multiple social and environmental goals. However, there is still a need for the clear articulation of what is meant by justice and for practical guidance that can be applied to sustainability decision-making processes.
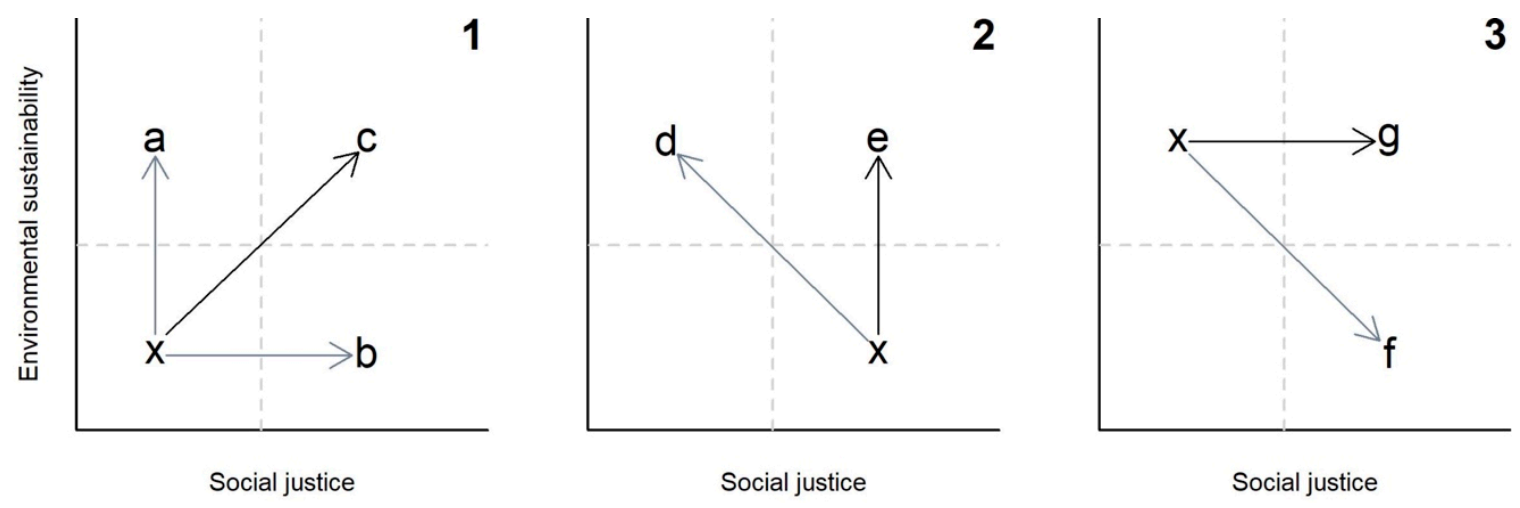

Figure 1. Heuristic models of transformations from initial social-ecological system states (x) towards future states. Just transformations are shown by the dark arrows where the outcome produced balances environmental sustainability (e.g., environmental health, ecosystem productivity, biodiversity, etc.) and social justice (e.g., distribution of wealth, opportunity and privileges). Lighter arrows show transformations that privilege either environmental sustainability or social justice as a rationale and outcome. The three panels show that the starting configuration (x) can be both unsustainable and unjust (1), unsustainable but just (2), or sustainable but unjust (3). The letters $c$, e, and $g$ represent just transformations, whereas the letters $a, b, d$, and $f$ fail to achieve just transformations towards sustainability.

Environmental justice literature, in particular, provides important insights and guidance here. A robust environmental justice literature emerged from critiques and empirical evidence of racial and social injustices in the siting of development projects that produce dangerous waste and pollutants [80-82]. While initially focused primarily on critiques of the inequitable distribution of environmental pollution and harms, the environmental justice literature has since been applied constructively to guide sustainability, conservation and adaptation decisions in a variety of geographical and environmental contexts [83-85]. While it is beyond the scope of this paper to review this extensive literature, here, we draw from the environmental justice literature, as well as conceptually linked literature on just transitions [58-61] and social equity [86-89], to suggest that recognitional, procedural, and distributional justice need to be taken into account during transformations towards sustainability (see also [90]). We derive from these literatures to suggest the following definitions for the three dimensions of justice:

- Recognitional justice refers to the acknowledgement of and respect for pre-existing governance arrangements as well as the distinct rights, worldviews, knowledge, needs, livelihoods, histories and cultures of different groups in decisions; 
- Procedural justice refers to the level of participation and inclusiveness of decision making and the quality of governance processes; and,

- Distributional justice can be defined as fairness in the distribution of benefits and harms of decisions and actions to different groups across space and time.

\section{Guidance to Manage Just Transformations towards Sustainability}

Below, we provide practical guidance for pursuing just transformations. First, drawing from our engagement with a broad set of literature on transformations, just transitions, and social justice reviewed above, we define just transformations and just transformation management as follows:

- Just transformations refers to radical shifts in social-ecological system configurations through forced, emergent or deliberate processes that produce balanced and beneficial outcomes for both social justice and environmental sustainability.

- Just transformation management consists of deliberate governance processes and actions taken to shift systems towards environmental sustainability and social justice outcomes in ways that account for recognitional, procedural and distributional concerns.

These definitions are explicitly normative, and the idea of just transformation management is prescriptive. It suggests that we need to actively incorporate the three elements of environmental justice into environmental sustainability decision-making processes. But, how? What guidance can help facilitate just transformations during environmental decision-making processes? What information or research is needed to support the management of just transformations? We contend that the management of just transformations will be improved through engagement with research and knowledge from a variety of different fields. Below, we provide both practical and methodological guidance for how environmental and sustainability decision-making processes might incorporate recognitional, procedural and distributional considerations to facilitate just transformations (Figure 2).

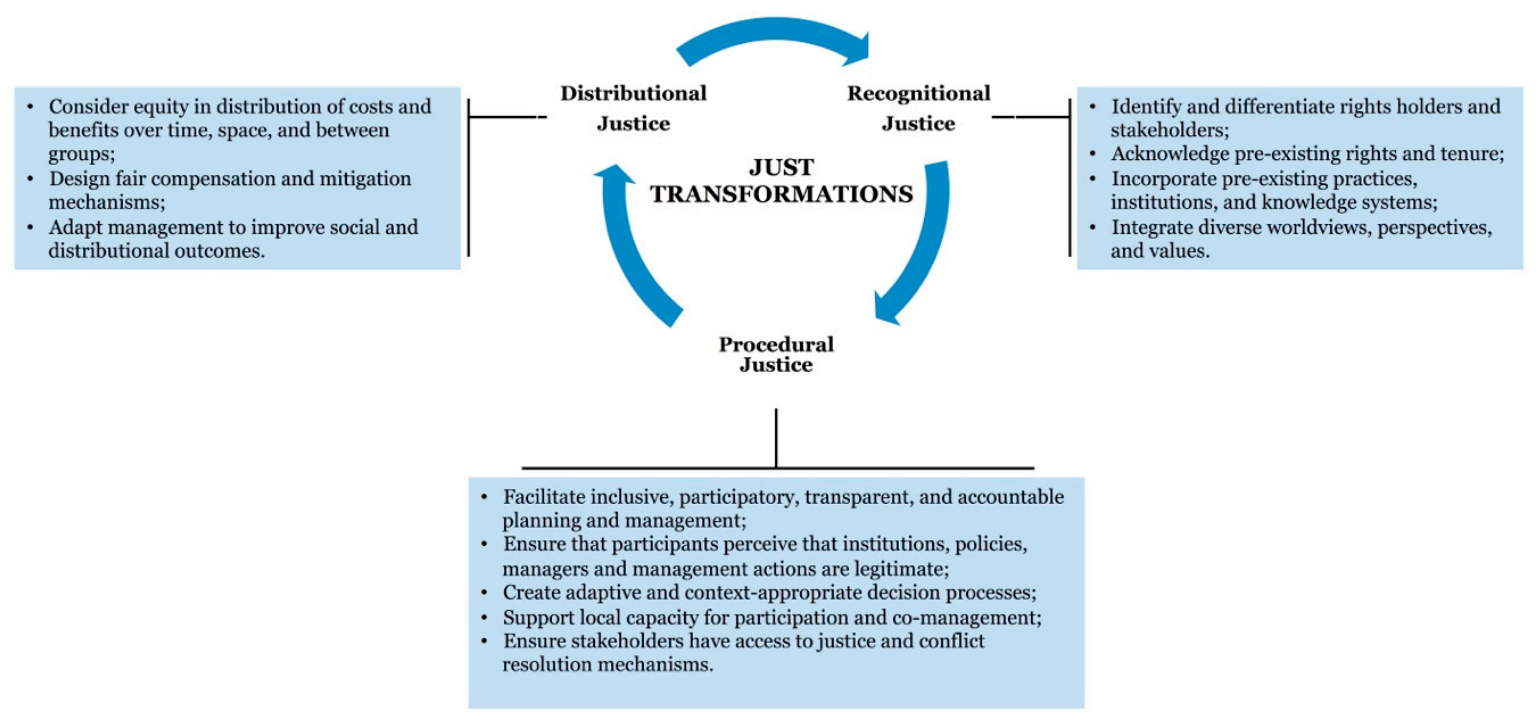

Figure 2. Key considerations and guidance for just transformation management.

\subsection{Recognitional Justice}

The recognition of all groups is the basis of all forms of justice; without it, neither procedural nor distributional justice will be possible for some groups. Recognitional justice requires first the identification of all interest groups and rights holders who are present in an area and who might be implicated by a sustainability initiative. Special attention needs to be paid to representing diverse interests and to ensuring the involvement of those who are often neglected or marginalized in decisions [91]. This might happen through a process of identifying and ensuring the salience of 
stakeholders [92-94]. An important next step is the documentation of the historical and current tenure and rights of the different groups to both land and resources. For example, the rights of some groups to areas or resources might be given preferential treatment under law while for other groups resources might be considered integral to their right to food. Research methods such as legal and policy reviews, mapping of indigenous and property rights and participatory spatial mapping of historical and current uses and rights can help to identify the legal allocations and spatial configuration of rights [95-98]. The recognition of and respect for the traditional practices and institutions, knowledge systems, cultures and worldviews, and values of diverse interest groups and rights holders will necessitate that steps are taken to both understand and to meaningfully integrate these considerations into environmental planning and management. Methods such as stakeholder analysis, participatory action research methods or social analysis systems could facilitate documentation, discussion, and incorporation of these factors into decision making [99-101]. The documentation of local and traditional knowledge [22,102,103] and mapping of diverse social and cultural values [104-106] can enable the integration of this information with scientific knowledge and ecological values in management and planning of sustainability initiatives.

\subsection{Procedural Justice}

More than just participation and inclusion, procedural justice requires engaging in a manner that ensures a broader set of qualities of good governance, such as transparency, accountability, legitimacy, responsiveness, capacity, and access to justice, are available to all actors [88,107-111]. Principles of participation and inclusion asks us to consider who will be included in decision making and how they will be included. Genuinely participatory decision making requires the development of governance structures that adequately represent all stakeholders and marginalized groups and well-facilitated processes that ensure that a diversity of voices and perspectives are heard [109,112]. Being truly inclusive may also necessitate designing contextually appropriate governance and collaborative management processes that consider capacity and timing needs, develop information sharing protocols, incorporate pre-existing governance structures and respect cultural differences. The autonomy and sovereignty of different nations, local communities and indigenous groups also need to be acknowledged, and respect for the right to self-determination provided through ensuring Free, Prior and Informed Consent (FPIC) [113-115]. The timely and accessible communication of scientific research and other information, of the way that decisions are made, and of the rationales for decisions to all parties provides transparency $[88,109,116]$. Upward and downward accountability mechanisms can help to ensure that parties are responsible for fulfilling their assigned duties and for other actions $[109,116]$. As a general rule, environmental sustainability initiatives need to be responsive and adaptable to different social contexts and to local people's needs [117,118]. Legitimacy is provided by law but can also be conferred by actors based on their perceptions of, trust in and support for sustainability actions $[109,118]$. Providing support for local capacity, as well as active development of local skills, ensures that local people can effectively participate in decision making and management $[119,120]$. Finally, access to justice and conflict transformation mechanisms can help to mediate differences between more and less powerful groups, and can help to redress for past wrongs $[21,28,114,121]$. Research can help to understand and enable procedural justice through descriptive assessments or normative evaluations of current governance institutions, structures and processes to document their current status, diagnose issues and aid in the re-design of more just governance processes $[107,109,118]$.

\subsection{Distributional Justice}

The concept of distributional justice refers to fairness in how different groups of people benefit from or incur the harms of environmental decisions and actions across space and time. As a management norm, distributional justice necessitates that we understand how different groups will be impacted by changes to resource access, allocations, benefits and harms during and after sustainability transformations. At the very least, facilitating just transformations will require identifying the potential 
economic costs and benefits of environmental and sustainability initiatives. Understanding net economic effects can be accomplished through a basic cost-benefit analysis [122]. However, to truly understand distributions this should be complemented by an analysis of how these economic costs and benefits of implementing a policy are dispersed: (a) between and within groups using, for example, indicators such as the Gini coefficient $[123,124]$; (b) both across space (i.e., to proximal and distant groups) using Gini coefficient as applied to analyze the distribution of high seas benefits under different management regimes in Sumaila et al. [125]; and (c) over time (i.e., before, during, and after the transformation, to current and future generations) by employing intergenerational cost-benefit analysis and discounting [126-128] and Gamma discounting [129]. These analyses can be useful as the basis for deliberations on what actions to take to facilitate just transformations. However, deciding what constitutes a fair or just distribution is complicated by underlying philosophies and 'equity criteria' (i.e., utility, equality, proportionality, needs, merit, and rights; defined in Table 1) that are often implicit in environmental and sustainability decision-making processes $[18,89,130,131]$. In Figure 3, we demonstrate how more explicit consideration of these different criteria might change the allocation of fisheries' catches to three different groups (i.e., indigenous or subsistence fishers, small-scale commercial fishers, and industrial scale commercial fishers) before, during and after the rebuilding of fish stocks. This scenario also demonstrates how both current distributions and historical rights and trends may need to go into the calculus of just distributions. Thus, a critical first step might be needed to right past wrongs through restitution.

Understanding the distribution of benefits and harms can be further complicated by the fact that sustainability initiatives impact not just economic, but also other social, cultural, physical and political aspects of human well-being that are valued by people [72,132]. For example, fisheries management successes as defined by economic (and sometimes ecological) objectives can be viewed negatively by communities due to an inequitable distribution of benefits, risking increased conflict and negative social outcomes [15]. This can be problematic given the non-monetary values-e.g., culture, identity, food security, and social cohesion - that are associated with fisheries, and that are particularly strong in the small-scale sector that comprises the vast majority of fisheries around the world $[72,133]$. There are numerous integrative frameworks and decision-making tools for characterizing and understanding the impacts of decisions on the different aspects of human well-being that groups receive from, for example, an environmental resource, ecosystem service or natural area [24,134-137].

Table 1. Implicit philosophies and equity criteria influence what is judged to be a fair or just distribution of outcomes.

\begin{tabular}{cc}
\hline Criteria & \multicolumn{1}{c}{ Descriptions } \\
\hline Utility & $\begin{array}{r}\text { Just actions are judged to be those that produce increases in aggregate goods and that } \\
\text { improve overall human well-being. Distribution is not considered. }\end{array}$ \\
\hline Equality & $\begin{array}{r}\text { All parties are deemed to be the same, and assumed to have equal opportunity, and thus } \\
\text { should be treated in exactly the same way. }\end{array}$ \\
\hline Proportional & $\begin{array}{r}\text { Assumes that future losses and gains should be proportional, but not equivalent, in value } \\
\text { based on current claims and allocations. }\end{array}$ \\
\hline Merit & $\begin{array}{r}\text { Preferential treatment should be given to the poorest, most vulnerable, and most in need. } \\
\text { costs-based on effort (e.g., work) and inputs (e.g., capacity, investments). Also referred } \\
\text { to as just desserts. }\end{array}$ \\
\hline Rights & $\begin{array}{r}\text { Treatment of different groups should ensure that minimum thresholds of basic human } \\
\text { rights are respected and depends on pre-existing rights (e.g., Indigenous people rights, } \\
\text { historical tenure). }\end{array}$ \\
\hline
\end{tabular}




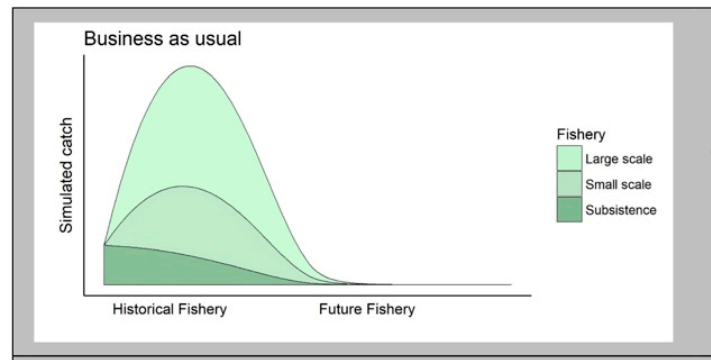

a) Business as usual scenario (none) - There is no recovery effort for stock being overfished. This leads to the collapse of the stock and negative impacts for all parties.

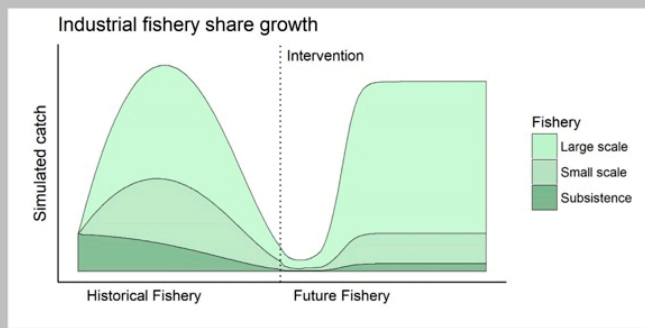

b) Industrial growth scenario (utility) - It is assumed that rebuilding will lead to net benefit. However, distribution is not considered. Industrial fisheries increase their share of catch due to their market power and ability to withstand initial catch declines during recovery efforts. Over time, quota and fishing licenses are consolidated with wealthy individuals and the largest corporations.

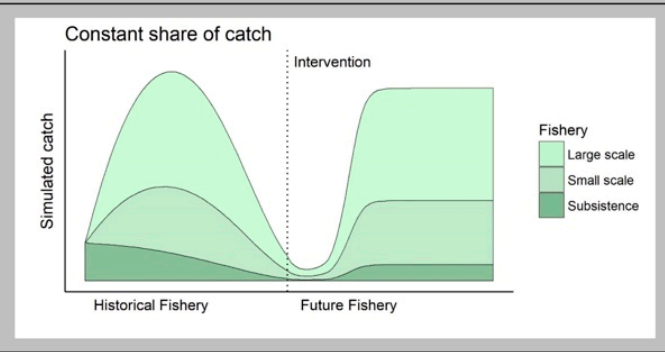

c) Constant shares scenario (proportional) - Recovery maintains the same proportion of shares (\%) of the catch to each group as at start of rebuilding process. Relative changes in losses and benefits are equal across sectors during and after rebuilding.

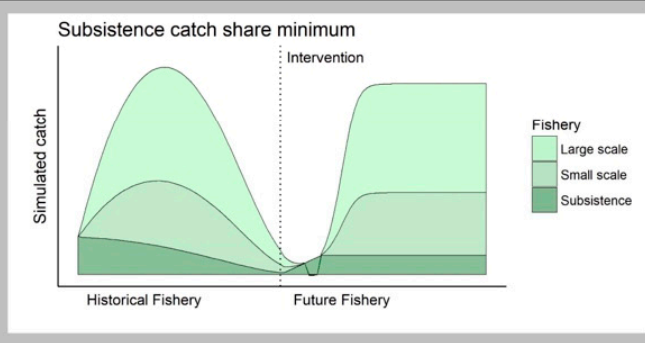

d) Subsistence rights scenario (rights) - A minimum catch is established for subsistence fleets at historical maximum based on the assumption of historical rights and food security needs. These rights are protected and maintained through the rebuilding period, while the catches of other groups are limited until stocks recover.

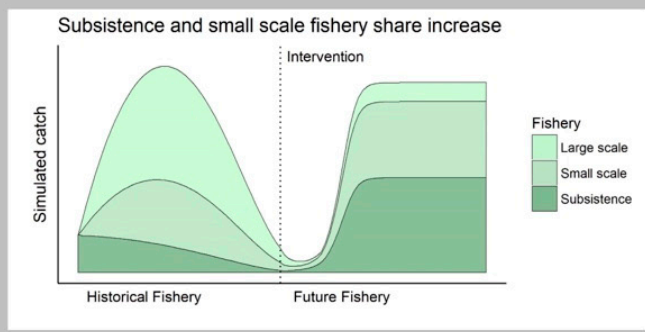

e) Subsistence and small-scale growth scenario (rights, needs and merit) - The rights and needs of subsistence and small scale fishing sectors are prioritized in rebuilding, so

that their shares of catch increase over time, with concomitant limits in quota for the industrial sector. To account for pre-existing capacity and investments (merit), a fair compensation scheme is created to mitigate the costs of lost benefits for the industrial sector.

Figure 3. Hypothetical scenarios of modeled distributions of fisheries' catches to three different groups (i.e., indigenous or subsistence fishers, small-scale commercial fishers, and industrial scale commercial fishers) before, during and after a transformation period (i.e., rebuilding stocks) based on the different equity criteria. Note that total catch after recovery is assumed to be equal for all scenarios (except business as usual); changes are to the allocation of catches during and after stock recovery.

Both economic and integrative assessments can help to guide decision making to identify actions, both during and after the transformation process, that may need to be taken to mitigate negative socio-economic impacts (e.g., compensation schemes, impact benefit agreements) and/or to promote socio-economic benefits (e.g., develop new opportunities or alternative livelihoods). Yet, the questions of who and how much to compensate different groups can be a challenging one, particularly for public resources such as fisheries, water and forests. When economic efficiency or environmental conservation are the overarching policy goals, issues related to who should benefit from resources may be considered 
less important. Compensation questions are usually limited to calculating an appropriate amount, for example, the net present value of fish quota in quota-based management systems, or estimated habitat or biodiversity values (i.e., carbon sequestration rates, fisheries or ecotourism revenue) in payments for ecosystem services programs. 'Fairness' in these cases is addressed by computing the values that different users are currently deriving from natural resources, or the average amount from recent years (e.g., average fishing revenue in the last five years for a given company). However, true transformations may create novel "losses", producing lost profit for historically privileged or wealthy groups (see Figure 3e). Should these additional losses be considered, and these groups be compensated during transformations? This is an ethical question that will need to be addressed in every case. Implementing ongoing programs to monitor the social impacts of environmental and sustainability initiatives, can also help to facilitate adaptive management of sustainability policies and practices for distributive justice [138]. Finally, throughout discussions of distribution, recognitional and procedural justice considerations would suggest that representatives of all rights- and stake-holder groups need to be included in selecting the indicators for valued components, in choosing the assumptions that go into allocation models and in deliberating on the management decisions that are ultimately taken.

\section{A Case Study of Fisheries in British Columbia, Canada}

To demonstrate how this thinking might guide environmental and sustainability decision-making processes, we turn our attention briefly to a case study of fisheries on the Pacific Coast of Canada. Our aim here is not to propose the solutions-but rather to provide a general description of the context and explore how the three social justice considerations might be taken into account. The current situation in coastal British Columbia (BC) might be characterized as follows: (a) historical declines in fisheries have led to a situation where many stocks are considered overfished or unsustainable and there is a recognized need to rebuild many fisheries [139-141]; (b) Indigenous fisheries were historically side-lined in favor of commercial fisheries [142], and although indigenous rights were enshrined in the Constitution Act of 1982 [143], court cases are still being fought and negotiations are taking place to ensure adequate allocation for cultural, subsistence and livelihood rights [144,145]; (c) While fisheries were an economic mainstay for many coastal communities during the 20th century, over recent decades fishing licenses, quota and benefits are becoming increasingly centralized and consolidated with less profits going to active fishermen and serious implications for coastal communities [124,146-149]; and (d) Governance and decision-making processes regarding fisheries management on the Pacific Coast are consultative rather than truly participatory [150-152], though a comprehensive evaluation of ocean governance processes in BC is lacking. In short, this is a challenging policy scenario that might be broadly characterized as approaching, if it is not already, a situation that is both ecologically unsustainable and socially unjust.

This brings us to the difficult question of how a just transformation towards environmental sustainability might occur. Incremental change will be insufficient to ameliorate the overlapping social and environmental issues in BC fisheries, a more radical transformation is required. Currently, some groups are advocating for better management and the rebuilding of fisheries while other groups are promoting actions to reallocate fishing licenses. We concur with the argument of both groups. Indeed, many fisheries will need to be rebuilt, and this may require decreases in overall fisheries harvests. However, fisheries management and marine conservation decisions will also need to struggle with questions related to recognitional, procedural and distributional justice. The question of how fisheries' catches will be distributed during and after the transformation to different groups, as well as how different groups might be compensated for losses incurred, will require discussion and negotiation based on a balanced consideration of utility, proportionality, needs, rights and merit (Table 1 and Figure 3). An important first step in this process will be to develop a solid understanding of the historical context and current status of both the fisheries and how catches were distributed to different groups-including indigenous fisheries, small-scale (owner-operator) fisheries, and commercial fisheries-who have actively fished on the coast. A subsequent step will be to recognize the pre-existing tenure and rights of 
these different groups and to examine how distinct circumstances and needs, governance institutions, local knowledge systems, cultural values and practices might be taken into account in decision-making. Procedural justice suggests that these different groups ought to be able to participate and have a say in the decision-making processes that employ good governance practices such as transparency, accountability, responsiveness, capacity and access to justice. Given the lack of past evaluations, the current governance processes may need to be first evaluated against indicators for good governance from the perspective of different stakeholder groups to identify necessary improvements. As will be discussed below, new spaces, governance processes, and capacity may be required (and indeed are already being created $[144,153])$ to navigate this transformation.

\section{Discussion: Addressing the Challenges of Navigating Just Transformations}

In this paper, we aim to bring recognitional, procedural and distributional justice considerations to the forefront in sustainability and transformations science, policy and practice. This implies that sustainability and environmental decision-making processes will need to ask: Who is implicated in sustainability decisions? Who should be included in decision making? How should decisions be made? How should distinct worldviews and cultures be considered? What will be the short and long-term impacts of decisions? Who will the winners and losers be? Engagement in sustainability transformations research and management, in particular, calls for reflection on the distribution of wealth, power, opportunities, and privileges within our societies. This is essential because all actions taken to shift towards environmental sustainability can have both positive and negative social implications for different groups relative to the status quo. Lack of consideration of local people's voice or needs in the pursuit of sustainability can also lead to lack of legitimacy, opposition and the active undermining of environmental sustainability policies. While the theoretical literature on sustainability transformations has touched on justice, it has not been adequately conceptualized as to be practicable. We consider this paper to be an extension of the past literature on transformations, just transitions, and social justice. It provides a novel contribution by bringing together these various strands of literature to characterize and provide practical and methodological guidance to support the pursuit of just transformations. Yet, we caution that this guidance should not be thought of as a blueprint, but rather as a flexible input into deliberations for how to navigate just transformations to sustainability in diverse social and ecological contexts.

Meaningful engagement with the principles associated with recognitional, procedural and distributional facets of social justice has the potential to be transformative for sustainability practice. Still, we are not naïve to the significant challenges that a social justice framing poses to those engaging with the daunting task of shifting society radically towards a more sustainable trajectory. Sustainability transformations are political, rife with power imbalances, a site of conflict and a source of social struggle $[10,28]$. International and national actions taken to promote environmental sustainability have been implicated in human rights abuses and other negative social consequences for indigenous groups and local communities $[17,21,70,154,155]$. Furthermore, the uncritical and ineffective application of collaboration and participatory approaches may simply reproduce previous injustices, namely inappropriate representation, uneven power dynamics, and the resultant lack of equity and legitimacy $[69,156,157]$. Explicitly engaging with social justice in environmental decision making may bring to the forefront challenges and issues that were previously simmering beneath the surface. We argue that the "airing" of these types of grievances and concerns may be necessary to proactively and properly address the structural imbalances, power differentials, race-based inequalities and other social justice challenges that could otherwise undermine sustainability initiatives in the long run.

Despite these challenges, scholars and practitioners are making intellectual and practical advances in moving social justice considerations into the heart of transformation research and management in several key areas. First, addressing the unique challenges posed by just transformations requires novel methods for engaging with entrenched inequality and marginalization. These can take the form of transdisciplinary methods, informed by multiple communities of knowledge, which generate 
problem-based and solution-oriented data to inform decision making [158]. Alternatively, recent research highlights collective imaginaries [159] and futures methods [160] as creative approaches for envisioning radically alternative, and co-created, futures. Novel analytical tools, such as the Inequality and Transformation Analysis (ITA) framework, enable explicit engagement with broad structural drivers of inequality and open the possibility for more equitable societal transformations [161]. Similarly, the Socio-environmental Conflict Transformation (SCT) framework [28,162] seeks to confront and subvert power relations that are interfering with more radical transformation processes. Second, the creation of transformative spaces is emerging as a promising mechanism for navigating equitable transformations. Transformative spaces refer to deliberately created environments (physical or metaphorical) where excluded or marginalized voices "shape normative agendas, assert alternative cognitive frames and visions, engage with and influence the social processes of governance, knowledge production, and practices, and alter the material conditions (e.g., ecological stocks and flows, infrastructure)" [163]. Transformative spaces can take many forms, including transformation labs [164] or novel conceptual and communicative spaces that are sensitive to power and gender dynamics [165]. Third, transformation thinkers are exploring how to enhance the transformative capacity of marginalized groups, whose voices have often been excluded from decision-making processes. Building transformational capacity can include actions such as accounting for the uneven distribution of transformative agency [166] or enlarging the capacity of marginalized groups to change or transform entrenched injustices [167].

\section{Conclusions}

In conclusion, we suggest that sustainability transformations cannot be considered a success without social justice. Indeed, one of the core tenets of the UN Sustainable Development Goals is to "Leave no one behind". Achieving this laudable aim will require that social justice is a central concern of sustainability practice. The road to environmental sustainability can be pursued in an inclusive or exclusionary manner and increase or decrease distributional justice. Our aim here is to inspire greater engagement with recognitional, procedural and distributional justice considerations during efforts to pursue transformations to sustainability. The framing of just transformations put forward here might be applied to guide decision making in a myriad of policy realms across marine, freshwater and terrestrial ecosystems, as well as urban and industrial settings and at various scales from local to global. Embedding the consideration of social justice at the heart of transformations research and management is our best way of ensuring more inclusive and just pathways towards sustainability.

Author Contributions: Individual contributions to this paper were as follows: conceptualization, N.J.B., G.G.S., A.M.C.-M. and J.B.; methodology, N.J.B. and A.M.C.-M.; literature review, N.J.B. and J.B.; writing-original draft preparation, N.J.B. and J.B..; writing-review and editing, N.J.B., J.B., A.M.C.-M., G.G.S., U.R.S.; visuals, A.C-M.; supervision, U.R.S.; funding acquisition, U.R.S.

Funding: This research was funded by the OceanCanada Partnership, through SSHRC Partnership Grant \#895-2013-1009 from the Social Sciences and Humanities Research Council of Canada.

Conflicts of Interest: The authors declare no conflict of interest. The funders had no role in the design of the study; in the collection, analyses, or interpretation of data; in the writing of the manuscript, or in the decision to publish the results.

\section{References}

1. Allsopp, M.; Page, R.; Johnston, P.; Santillo, D. State of the World's Oceans; Springer: New York, NY, USA, 2009; ISBN 978-1-4020-9115-5.

2. Steffen, W.; Richardson, K.; Rockström, J.; Cornell, S.E.; Fetzer, I.; Bennett, E.M.; Biggs, R.; Carpenter, S.R.; de Vries, W.; de Wit, C.A.; et al. Planetary boundaries: Guiding human development on a changing planet. Science 2015, 347, 1259855. [CrossRef] [PubMed]

3. Nash, K.L.; Cvitanovic, C.; Fulton, E.A.; Halpern, B.S.; Milner-Gulland, E.J.; Watson, R.A.; Blanchard, J.L. Planetary boundaries for a blue planet. Nat. Ecol. Evol. 2017, 1, 1625. [CrossRef] [PubMed] 
4. IPBES. Summary for Policymakers of the Global Assessment Report on Biodiversity and Ecosystem Services of the Intergovernmental Science-Policy Platform on Biodiversity and Ecosystem Services; Intergovernmental Science-Policy Platform on Biodiversity and Ecosystem Services: Bonn, Germany, 2019.

5. UN Environment. Global Environment Outlook-GEO-6: Healthy Planet, Healthy People; Cambridge Open Access: Nairobi, Kenya, 2019; ISBN 978-1-108-62714-6.

6. Future Earth Transformations. Available online: http://futureearth.org/future-earth-transformations (accessed on 1 April 2019).

7. Díaz, S.; Demissew, S.; Carabias, J.; Joly, C.; Lonsdale, M.; Ash, N.; Larigauderie, A.; Adhikari, J.R.; Arico, S.; Báldi, A.; et al. The IPBES Conceptual Framework-Connecting nature and people. Curr. Opin. Environ. Sustain. 2015, 14, 1-16. [CrossRef]

8. UN. Transforming Our World: The 2030 Agenda for Sustainable Development; United Nations: New York, NY, USA, 2015.

9. Bennett, N.J.; Whitty, T.S.; Finkbeiner, E.; Pittman, J.; Bassett, H.; Gelcich, S.; Allison, E.H. Environmental Stewardship: A Conceptual Review and Analytical Framework. Environ. Manag. 2018, 61, 597-614. [CrossRef] [PubMed]

10. Blythe, J.; Silver, J.; Evans, L.; Armitage, D.; Bennett, N.J.; Moore, M.L.; Morrison, T.H.; Brown, K. The Dark Side of Transformation: Latent Risks in Contemporary Sustainability Discourse. Antipode 2018, 50, 1206-1223. [CrossRef]

11. Sumaila, U.R.; Cheung, W.; Dyck, A.; Gueye, K.; Huang, L.; Lam, V.; Pauly, D.; Srinivasan, T.; Swartz, W.; Watson, R.; et al. Benefits of Rebuilding Global Marine Fisheries Outweigh Costs. PLoS ONE 2012, 7, e40542. [CrossRef]

12. Daw, T.; Brown, K.; Rosendo, S.; Pomeroy, R. Applying the ecosystem services concept to poverty alleviation: The need to disaggregate human well-being. Environ. Conserv. 2011, 38, 370-379. [CrossRef]

13. Giron-Nava, A.; Johnson, A.F.; Cisneros-Montemayor, A.M.; Aburto-Oropeza, O. Managing at Maximum Sustainable Yield does not ensure economic well-being for artisanal fishers. Fish Fish. 2018, 20, $214-223$. [CrossRef]

14. Hicks, C.C.; Cinner, J.E. Social, institutional, and knowledge mechanisms mediate diverse ecosystem service benefits from coral reefs. Proc. Natl. Acad. Sci. USA 2014, 111, 17791-17796. [CrossRef]

15. Klain, S.C.; Beveridge, R.; Bennett, N.J. Ecologically sustainable but unjust? Negotiating equity and authority in common-pool marine resource management. Ecol. Soc. 2014, 19, 52. [CrossRef]

16. Raudsepp-Hearne, C.; Peterson, G.D.; Tengö, M.; Bennett, E.M.; Holland, T.; Benessaiah, K.; MacDonald, G.K.; Pfeifer, L. Untangling the Environmentalist's Paradox: Why Is Human Well-being Increasing as Ecosystem Services Degrade? BioScience 2010, 60, 576-589. [CrossRef]

17. West, P.; Igoe, J.; Brockington, D. Parks and peoples: The social impact of protected areas. Annu. Rev. Anthropol. 2006, 35, 251-277. [CrossRef]

18. Martin, A.; McGuire, S.; Sullivan, S. Global environmental justice and biodiversity conservation. Geogr. J. 2013, 179, 122-131. [CrossRef]

19. Ratner, B.D.; Åsgård, B.; Allison, E.H. Fishing for justice: Human rights, development, and fisheries sector reform. Glob. Environ. Chang. 2014, 27, 120-130. [CrossRef]

20. Friedman, R.S.; Law, E.A.; Bennett, N.J.; Ives, C.D.; Thorn, J.P.R.; Wilson, K.A. How just and just how? A systematic review of social equity in conservation research. Environ. Res. Lett. 2018, 13, 053001. [CrossRef]

21. Bennett, N.J.; Teh, L.; Ota, Y.; Christie, P.; Ayers, A.; Day, J.C.; Franks, P.; Gill, D.; Gruby, R.L.; Kittinger, J.N.; et al. An appeal for a code of conduct for marine conservation. Mar. Policy 2017, 81, 411-418. [CrossRef]

22. Blythe, J.; Cohen, P.; Abernathy, K.; Evans, L. Navigating transformation to community-based resource management. In Governing the Coastal Commons: Communities, Resilience and Transformation; Armitage, D., Charles, A., Berkes, F., Eds.; Taylor and Francis: Milton Park, Didcott, UK, 2017; ISBN 978-1-317-42128-3.

23. Kittinger, J.N.; Teh, L.C.L.; Allison, E.H.; Bennett, N.J.; Crowder, L.B.; Finkbeiner, E.M.; Hicks, C.; Scarton, C.G.; Nakamura, K.; Ota, Y.; et al. Committing to socially responsible seafood. Science 2017, 356, 912-913. [CrossRef] [PubMed]

24. Stephenson, R.L.; Benson, A.J.; Brooks, K.; Charles, A.; Degnbol, P.; Dichmont, C.M.; Kraan, M.; Pascoe, S.; Paul, S.D.; Rindorf, A.; et al. Practical steps toward integrating economic, social and institutional elements in fisheries policy and management. ICES J. Mar. Sci. 2017, 74, 1981-1989. [CrossRef] 
25. Christie, P. Marine protected areas as biological successes and social failures in Southeast Asia. Am. Fish. Soc. Symp. 2004, 42, 155-164.

26. Bennett, N.J.; Dearden, P. Why local people do not support conservation: Community perceptions of marine protected area livelihood impacts, governance and management in Thailand. Mar. Policy 2014, 44, 107-116. [CrossRef]

27. Patterson, J.J.; Thaler, T.; Hoffmann, M.; Hughes, S.; Oels, A.; Chu, E.; Mert, A.; Huitema, D.; Burch, S.; Jordan, A. Political feasibility of $1.5^{\circ} \mathrm{C}$ societal transformations: The role of social justice. Curr. Opin. Environ. Sustain. 2018, 31, 1-9. [CrossRef]

28. Temper, L.; Walter, M.; Rodriguez, I.; Kothari, A.; Turhan, E. A perspective on radical transformations to sustainability: Resistances, movements and alternatives. Sustain. Sci. 2018, 13, 747-764. [CrossRef]

29. Ellis, N.R.; Tschakert, P. Triple-wins as pathways to transformation? A critical review. Geoforum 2018, 103, 167-170. [CrossRef]

30. O'Brien, K. Global environmental change II: From adaptation to deliberate transformation. Prog. Hum. Geogr. 2012, 36, 667-676. [CrossRef]

31. Shah, S.S.; Rodina, L.; Burt, J.M.; Gregr, E.J.; Chapman, M.; Williams, S.; Wilson, N.J.; McDowell, G. Unpacking social-ecological transformations: Conceptual, ethical and methodological insights. Anthr. Rev. 2018, 5, 250-265. [CrossRef]

32. Kates, R.W.; Travis, W.R.; Wilbanks, T.J. Transformational adaptation when incremental adaptations to climate change are insufficient. Proc. Natl. Acad. Sci. USA 2012, 109, 7156-7161. [CrossRef] [PubMed]

33. IPCC Summary for Policymakers. Managing the Risks of Extreme Events and Disasters to Advance Climate Change Adaptation: Special Report of the Intergovernmental Panel on Climate Change; Field, C.B., Barros, V., Stocker, T.F., Dahe, Q., Eds.; Cambridge University Press: Cambridge, NY, USA, 2012; ISBN 978-1-107-38010-3.

34. Pelling, M. Adaptation to Climate Chang. From Resilience to Transformation; Routledge: Abington, UK, 2010; ISBN 978-1-134-02202-1.

35. Grin, J.; Rotmans, J.; Schot, J. Transitions to Sustainable Development: New Directions in the Study of Long Term Transformative Change; Routledge: Abington, UK, 2010; ISBN 978-1-135-15117-1.

36. Geels, F.W.; Sovacool, B.K.; Schwanen, T.; Sorrell, S. Sociotechnical transitions for deep decarbonization. Science 2017, 357, 1242-1244. [CrossRef]

37. Geels, F.W.; Schot, J. Typology of sociotechnical transition pathways. Res. Policy 2007, 36, 399-417. [CrossRef]

38. Hölscher, K.; Wittmayer, J.M.; Loorbach, D. Transition versus transformation: What's the difference? Environ. Innov. Soc. Transit. 2018, 27, 1-3. [CrossRef]

39. Rotmans, J.; Fischer-Kowalski, M. Conceptualizing, observing and influencing socio-ecological transitions. Ecol. Soc. 2009, 14. Available online: http://www.ecologyandsociety.org/vol14/iss2/art3 (accessed on 30 June 2019).

40. Loorbach, D.; Rotmans, J. The practice of transition management: Examples and lessons from four distinct cases. Futures 2010, 42, 237-246. [CrossRef]

41. Loorbach, D.; Frantzeskaki, N.; Avelino, F. Sustainability Transitions Research: Transforming Science and Practice for Societal Change. Annu. Rev. Environ. Resour. 2017, 42, 599-626. [CrossRef]

42. Rotmans, J.; Kemp, R.; van Asselt, M. More evolution than revolution: Transition management in public policy. Foresight 2001, 3, 15-31. [CrossRef]

43. Scoones, I.; Leach, M.; Newell, P. The Politics of Green Transformations; Routledge: Abington, UK, 2015; ISBN 978-1-317-60112-8.

44. Westley, F.R.; Tjornbo, O.; Schultz, L.; Olsson, P.; Folke, C.; Crona, B.; Bodin, Ö. A Theory of Transformative Agency in Linked Social-Ecological Systems. Ecol. Soc. 2013, 18, 27. [CrossRef]

45. Moore, M.-L.; Tjornbo, O.; Enfors, E.; Knapp, C.; Hodbod, J.; Baggio, J.A.; Norström, A.; Olsson, P.; Biggs, D. Studying the complexity of change: Toward an analytical framework for understanding deliberate social-ecological transformations. Ecol. Soc. 2014, 19, 54. [CrossRef]

46. Olsson, P.; Moore, M.-L.; Westley, F.; McCarthy, D. The concept of the Anthropocene as a game-changer: A new context for social innovation and transformations to sustainability. Ecol. Soc. 2017, 22. Available online: https://doi.org/10.5751/ES-09310-220231 (accessed on 30 June 2019).

47. Folke, C.; Kofinas, G.P.; Chapin, F.S., III. (Eds.) Principles of Ecosystem Stewardship; Springer: New York, NY, USA, 2009; ISBN 978-0-387-73032-5. 
48. Walker, B.; Holling, C.S.; Carpenter, S.R.; Kinzig, A. Resilience, Adaptability and Transformability in Social-ecological Systems. Ecol. Soc. 2004, 9, 5. [CrossRef]

49. Park, S.E.; Marshall, N.A.; Jakku, E.; Dowd, A.M.; Howden, S.M.; Mendham, E.; Fleming, A. Informing adaptation responses to climate change through theories of transformation. Glob. Environ. Chang. 2012, 22, 115-126. [CrossRef]

50. Leach, M.; Rockström, J.; Raskin, P.; Scoones, I.; Stirling, A.C.; Smith, A.; Thompson, J.; Millstone, E.; Ely, A.; Arond, E.; et al. Transforming Innovation for Sustainability. Ecol. Soc. 2012, 17, 11. [CrossRef]

51. Fazey, I.; Wise, R.M.; Lyon, C.; Câmpeanu, C.; Moug, P.; Davies, T.E. Past and future adaptation pathways. Clim. Dev. 2016, 8, 26-44. [CrossRef]

52. Geels, F.W. The multi-level perspective on sustainability transitions: Responses to seven criticisms. Environ. Innov. Soc. Transit. 2011, 1, 24-40. [CrossRef]

53. Van den Bergh, J.C.J.M.; Truffer, B.; Kallis, G. Environmental innovation and societal transitions: Introduction and overview. Environ. Innov. Soc. Transit. 2011, 1,1-23. [CrossRef]

54. Swilling, M.; Musango, J.; Wakeford, J. Developmental States and Sustainability Transitions: Prospects of a Just Transition in South Africa. J. Environ. Policy Plan. 2016, 18, 650-672. [CrossRef]

55. Newell, P.; Mulvaney, D. The political economy of the "just transition". Geogr. J. 2013, 179, 132-140. [CrossRef]

56. Grasso, M. Justice in Funding Adaptation under the International Climate Change Regime; Springer Science and Business Media: New York, NY, USA, 2009; ISBN 978-90-481-3439-7.

57. Okereke, C. Climate justice and the international regime. Wiley Interdiscip. Rev. Clim. Chang. 2010, 1, 462-474. [CrossRef]

58. Swilling, M.; Annecke, E. Just Transitions: Explorations of Sustainability in an Unfair World; UCT Press: Cape Town, South Africa, 2012; ISBN 978-92-808-1203-9.

59. Evans, G.; Phelan, L. Transition to a post-carbon society: Linking environmental justice and just transition discourses. Energy Policy 2016, 99, 329-339. [CrossRef]

60. McCauley, D.; Heffron, R. Just transition: Integrating climate, energy and environmental justice. Energy Policy 2018, 119, 1-7. [CrossRef]

61. Goddard, G.; Farrelly, M.A. Just transition management: Balancing just outcomes with just processes in Australian renewable energy transitions. Appl. Energy 2018, 225, 110-123. [CrossRef]

62. Williams, S.; Doyon, A. Justice in energy transitions. Environ. Innov. Soc. Transit. 2019, 31, 144-153. [CrossRef]

63. Scoones, I.; Stirling, A.; Abrol, D.; Atela, J.; Charlie-Joseph, L.; Eakin, H.; Ely, A.; Olsson, P.; Pereira, L.; Priya, R.; et al. Transformations to Sustainability; STEPS Working Paper 104; STEPS Centre: Brighton, UK, 2018.

64. Feola, G. Societal transformation in response to global environmental change: A review of emerging concepts. Ambio 2015, 44, 376-390. [CrossRef]

65. Capistrano, R.C.G.; Charles, A.T. Indigenous rights and coastal fisheries: A framework of livelihoods, rights and equity. Ocean Coast. Manag. 2012, 69, 200-209. [CrossRef]

66. Kleiber, D.; Harris, L.M.; Vincent, A.C.J. Gender and small-scale fisheries: A case for counting women and beyond. Fish Fish. 2015, 16, 547-562. [CrossRef]

67. Charles, A.; Westlund, L.; Bartley, D.M.; Fletcher, W.J.; Garcia, S.; Govan, H.; Sanders, J. Fishing livelihoods as key to marine protected areas: Insights from the World Parks Congress. Aquat. Conserv. Mar. Freshw. Ecosyst. 2016, 26, 165-184. [CrossRef]

68. Tam, C.-L. Timing exclusion and communicating time: A spatial analysis of participation failure in an Indonesian MPA. Mar. Policy 2015, 54, 122-129. [CrossRef]

69. Flannery, W.; Healy, N.; Luna, M. Exclusion and non-participation in Marine Spatial Planning. Mar. Policy 2018, 88, 32-40. [CrossRef]

70. West, P.; Brockington, D. An anthropological perspective on some unexpected consequences of protected areas. Conserv. Biol. 2006, 20, 609-616. [CrossRef]

71. Kamat, V. "The Ocean is our Farm": Marine Conservation, Food Insecurity, and Social Suffering in Southeastern Tanzania. Hum. Organ. 2014, 73, 289-298. [CrossRef]

72. Weeratunge, N.; Béné, C.; Siriwardane, R.; Charles, A.; Johnson, D.; Allison, E.H.; Nayak, P.K.; Badjeck, M.-C. Small-scale fisheries through the wellbeing lens. Fish Fish. 2014, 15, 255-279. [CrossRef]

73. Sommerville, M.; Jones, J.P.G.; Rahajaharison, M.; Milner-Gulland, E.J. The role of fairness and benefit distribution in community-based Payment for Environmental Services interventions: A case study from Menabe, Madagascar. Ecol. Econ. 2010, 69, 1262-1271. [CrossRef] 
74. Cinner, J.E.; Daw, T.; Huchery, C.; Thoya, P.; Wamukota, A.; Cedras, M.; Abunge, C. Winners and losers in marine conservation: fishers' displacement and livelihood benefits from marine reserves. Soc. Nat. Resour. 2014, 27, 994-1005. [CrossRef]

75. Green, J.M.H.; Fisher, B.; Green, R.E.; Makero, J.; Platts, P.J.; Robert, N.; Schaafsma, M.; Turner, R.K.; Balmford, A. Local costs of conservation exceed those borne by the global majority. Glob. Ecol. Conserv. 2018, 14, e00385. [CrossRef]

76. Iversen, V.; Chhetry, B.; Francis, P.; Gurung, M.; Kafle, G.; Pain, A.; Seeley, J. High value forests, hidden economies and elite capture: Evidence from forest user groups in Nepal's Terai. Ecol. Econ. 2006, 58, 93-107. [CrossRef]

77. Artur, L.; Hilhorst, D. Everyday realities of climate change adaptation in Mozambique. Glob. Environ. Chang. 2012, 22, 529-536. [CrossRef]

78. Schmidt, O.; Theesfeld, I. Elite capture in local fishery management-Experiences from post-socialist Albania. Int. J. Agric. Resour. Gov. Ecol. 2012, 9, 103-120.

79. Persha, L.; Andersson, K. Elite capture risk and mitigation in decentralized forest governance regimes. Glob. Environ. Change 2014, 24, 265-276. [CrossRef]

80. Cutter, S.L. Race, class and environmental justice. Prog. Hum. Geogr. 1995, 19, 111-122. [CrossRef]

81. Bullard, R.D. The Quest for Environmental Justice: Human Rights and the Politics of Pollution; Sierra Club Books: San Francisco, CA, USA, 2005; ISBN 978-1-57805-120-5.

82. Bullard, R.D. Dumping in Dixie: Race, Class, and Environmental Quality, Third Edition; Routledge: New York, NY, USA, 2018; ISBN 978-0-429-97490-8.

83. Schlosberg, D. Defining Environmental Justice: Theories, Movements, and Nature; Oxford University Press: New York, NY, USA, 2009; ISBN 978-0-19-956248-0.

84. Walker, G. Environmental Justice: Concepts, Evidence and Politics; Routledge: New York, NY, USA, 2012; ISBN 978-1-136-61924-3.

85. Agyeman, J.; Schlosberg, D.; Craven, L.; Matthews, C. Trends and Directions in Environmental Justice: From Inequity to Everyday Life, Community, and Just Sustainabilities. Annu. Rev. Environ. Resour. 2016, 41, 321-340. [CrossRef]

86. McDermott, M.; Mahanty, S.; Schreckenberg, K. Examining equity: A multidimensional framework for assessing equity in payments for ecosystem services. Environ. Sci. Policy 2013, 33, 416-427. [CrossRef]

87. Pascual, U.; Phelps, J.; Garmendia, E.; Brown, K.; Corbera, E.; Martin, A.; Gomez-Baggethun, E.; Muradian, R. Social equity matters in payments for ecosystem services. BioScience 2014, 64, 1027-1036. [CrossRef]

88. Zafra-Calvo, N.; Pascual, U.; Brockington, D.; Coolsaet, B.; Cortes-Vazquez, J.A.; Gross-Camp, N.; Palomo, I.; Burgess, N.D. Towards an indicator system to assess equitable management in protected areas. Biol. Conserv. Part A 2017, 211, 134-141. [CrossRef]

89. Franks, P.; Booker, F.; Roe, D. Understanding and assessing equity in protected area conservation; IIED Issue Paper; IIED: London, UK, 2018.

90. Fraser, N. Social Justice in the Age of Identity Politics: Redistribution, Recognition, and Participation. Tann. Lect. Hum. Values 1998, 19, 2-67.

91. Chambers, R. Sustainable Livelihoods, Environment and Development: Putting Poor Rural People First; IDS Discussion Paper 240; IDS University of Sussex: Sussex, Brighton, UK, 1987.

92. Ravnborg, H.M.; Westermann, O. Understanding interdependencies: Stakeholder identification and negotiation for collective natural resource management. Agric. Syst. 2002, 73, 41-56. [CrossRef]

93. Prell, C.; Hubacek, K.; Reed, M. Stakeholder Analysis and Social Network Analysis in Natural Resource Management. Soc. Nat. Resour. 2009, 22, 501-518. [CrossRef]

94. Luyet, V.; Schlaepfer, R.; Parlange, M.B.; Buttler, A. A framework to implement Stakeholder participation in environmental projects. J. Environ. Manag. 2012, 111, 213-219. [CrossRef]

95. Mohamed, M.A.; Ventura, S.J. Use of Geomatics for Mapping and Documenting Indigenous Tenure Systems. Soc. Nat. Resour. 2000, 13, 223-236. [CrossRef]

96. Robiglio, V.; Mala, W.A.; Diaw, M.C. Mapping landscapes: Integrating GIS and social science methods to model human-nature relationships in Southern Cameroon. Small-Scale For. Econ. Manag. Policy 2003, 2, 171-184.

97. Capistrano, R.C.G. Reclaiming the ancestral waters of indigenous peoples in the Philippines: The Tagbanua experience with fishing rights and indigenous rights. Mar. Policy 2010, 34, 453-460. [CrossRef] 
98. Ramirez-Gomez, S.O.I.; Brown, G.; Verweij, P.A.; Boot, R. Participatory mapping to identify indigenous community use zones: Implications for conservation planning in southern Suriname. J. Nat. Conserv. 2016, 29, 69-78. [CrossRef]

99. Kindon, S.; Pain, R.; Kesby, M. Participatory Action Research Approaches and Methods: Connecting People, Participation and Place; Routledge: New York, NY, USA, 2007; ISBN 978-0-415-40550-8.

100. Reed, M.S.; Graves, A.; Dandy, N.; Posthumus, H.; Hubacek, K.; Morris, J.; Prell, C.; Quinn, C.H.; Stringer, L.C. Who's in and why? A typology of stakeholder analysis methods for natural resource management. J. Environ. Manag. 2009, 90, 1933-1949. [CrossRef]

101. Chevalier, J.M.; Buckles, D.J. Participatory Action Research: Theory and Methods for Engaged Inquiry; Routledge: New York, NY, USA, 2013; ISBN 978-0-415-54031-5.

102. Berkes, F. Sacred Ecology: Traditional Ecological Knowledge and Resource Management; Taylor and Francis: Philadelphia, London, UK, 1999; ISBN 1-56032-694-8.

103. Thornton, T.F.; Scheer, A.M. Collaborative Engagement of Local and Traditional Knowledge and Science in Marine Environments: A Review. Ecol. Soc. 2012, 17, 8. [CrossRef]

104. Raymond, C.M.; Fazey, I.; Reed, M.S.; Stringer, L.C.; Robinson, G.M.; Evely, A.C. Integrating local and scientific knowledge for environmental management. J. Environ. Manag. 2010, 91, 1766-1777. [CrossRef]

105. Ban, N.C.; Mills, M.; Tam, J.; Hicks, C.C.; Klain, S.; Stoeckl, N.; Bottrill, M.C.; Levine, J.; Pressey, R.L.; Satterfield, T.; et al. A social-ecological approach to conservation planning: Embedding social considerations. Front. Ecol. Environ. 2013, 11, 194-202. [CrossRef]

106. Gee, K.; Kannen, A.; Adlam, R.; Brooks, C.; Chapman, M.; Cormier, R.; Fischer, C.; Fletcher, S.; Gubbins, M.; Shucksmith, R.; et al. Identifying culturally significant areas for marine spatial planning. Ocean Coast. Manag. 2017, 136, 139-147. [CrossRef]

107. Graham, J.; Amos, B.; Plumtree, T. Governance Principles for Protected Areas in the 21st Century; Institute on Governance, Parks Canada, and CIDA: Ottawa, ON, Canada, 2003; p. 50.

108. Elahi, K.Q. UNDP on good governance. Int. J. Soc. Econ. 2009, 36, 1167-1180. [CrossRef]

109. Lockwood, M.; Davidson, J.; Curtis, A.; Stratford, E.; Griffith, R. Governance principles for natural resource management. Soc. Nat. Resour. 2010, 23, 986-1001. [CrossRef]

110. Decker, D.; Smith, C.; Forstchen, A.; Hare, D.; Pomeranz, E.; Doyle-Capitman, C.; Schuler, K.; Organ, J. Governance Principles for Wildlife Conservation in the 21st Century. Conserv. Lett. 2016, 9, 290-295. [CrossRef]

111. Kim, M.K.; Evans, L.; Scherl, L.M.; Marsh, H. Applying Governance Principles to Systematic Conservation Decision-Making in Queensland. Environ. Policy Gov. 2016, 26, 452-467. [CrossRef]

112. Reed, M.S. Stakeholder participation for environmental management: A literature review. Biol. Conserv. 2008, 141, 2417-2431. [CrossRef]

113. Esteves, A.M.; Franks, D.; Vanclay, F. Social impact assessment: The state of the art. Impact Assess. Proj. Apprais. 2012, 30, 34-42. [CrossRef]

114. FAO (Ed.) Voluntary Guidelines on the Responsible Governance of Tenure of Land, Fisheries and Forests in the Context of National Food Security; Food and Agriculture Organization of the United Nations: Rome, Italy, 2012; ISBN 978-92-5-107277-6.

115. Mawyer, A.; Jacka, J.K. Sovereignty, conservation and island ecological futures. Environ. Conserv. 2018, 45, 238-251. [CrossRef]

116. Secco, L.; Da Re, R.; Pettenella, D.M.; Gatto, P. Why and how to measure forest governance at local level: A set of indicators. For. Policy Econ. 2014, 49, 57-71. [CrossRef]

117. Epstein, G.; Pittman, J.; Alexander, S.M.; Berdej, S.; Dyck, T.; Kreitmair, U.; Raithwell, K.J.; Villamayor-Tomas, S.; Vogt, J.; Armitage, D. Institutional fit and the sustainability of social-ecological systems. Curr. Opin. Environ. Sustain. 2015, 14, 34-40. [CrossRef]

118. Bennett, N.J.; Satterfield, T. Environmental governance: A practical framework to guide design, evaluation, and analysis. Conserv. Lett. 2018, 11, e12600. [CrossRef]

119. Armitage, D.; Berkes, F.; Doubleday, N. Adaptive Co-Management: Collaboration, Learning, and Multi-Level Governance; UBC Press: Vancouver, BC, Canada, 2010; ISBN 978-0-7748-5972-1.

120. Wyborn, C.A. Connecting knowledge with action through coproductive capacities: Adaptive governance and connectivity conservation. Ecol. Soc. 2015, 20, 11. [CrossRef] 
121. Borrini-Feyerabend, G.; Hill, R. Governance for the conservation of nature. In Protected Area Governance and Management; Worboys, G.L., Lockwood, M., Kothari, A., Feary, S., Pulsford, I., Eds.; ANU Press: Canberra, Australia, 2015; pp. 169-206.

122. Pearce, D.W.; Atkinson, G.; Mourato, S. Cost-Benefit Analysis and the Environment: Recent Developments; Organisation for Economic Co-operation and Development: Paris, France, 2006; ISBN 978-92-64-01004-8.

123. Atkinson, A.B. On the measurement of inequality. J. Econ. Theory 1970, 2, 244-263. [CrossRef]

124. Haas, A.R.; Edwards, D.N.; Sumaila, U.R. Corporate concentration and processor control: Insights from the salmon and herring fisheries in British Columbia. Mar. Policy 2016, 68, 83-90. [CrossRef]

125. Sumaila, U.R.; Lam, V.W.Y.; Miller, D.D.; Teh, L.; Watson, R.A.; Zeller, D.; Cheung, W.W.L.; Côté, I.M.; Rogers, A.D.; Roberts, C.; et al. Winners and losers in a world where the high seas is closed to fishing. Sci. Rep. 2015, 5, 8481. [CrossRef] [PubMed]

126. Sumaila, U.R. Intergenerational cost-benefit analysis and marine ecosystem restoration. Fish Fish. 2004, 5, 329-343. [CrossRef]

127. Ainsworth, C.H.; Sumaila, U.R. Intergenerational valuation of fisheries resources can justify long-term conservation: A case study in Atlantic cod (Gadus morhua). Can. J. Fish. Aquat. Sci. 2005, 62, 1104-1110. [CrossRef]

128. Sumaila, U.R.; Walters, C. Intergenerational discounting: A new intuitive approach. Ecol. Econ. 2005, 52, 135-142. [CrossRef]

129. Weitzman, M.L. Gamma Discounting. Am. Econ. Rev. 2001, 91, 260-271. [CrossRef]

130. Chan, K.M.A.; Satterfield, T. Justice, equity and biodiversity. Encycl. Biodivers. 2013, 4, 434-441.

131. Sikor, T.; Martin, A.; Fisher, J.; He, J. Toward an Empirical Analysis of Justice in Ecosystem Governance: Justice in ecosystem governance. Conserv. Lett. 2014, 7, 524-532. [CrossRef]

132. Breslow, S.J.; Sojka, B.; Barnea, R.; Basurto, X.; Carothers, C.; Charnley, S.; Coulthard, S.; Dolšak, N.; Donatuto, J.; García-Quijano, C.; et al. Conceptualizing and operationalizing human wellbeing for ecosystem assessment and management. Environ. Sci. Policy 2016, 66, 250-259. [CrossRef]

133. Cisneros-Montemayor, A.M.; Pauly, D.; Weatherdon, L.V.; Ota, Y. A Global Estimate of Seafood Consumption by Coastal Indigenous Peoples. PLoS ONE 2016, 11, e0166681. [CrossRef] [PubMed]

134. Igoe, J. Measuring the costs and benefits of conservation to local communities. J. Ecol. Anthropol. 2006, 10, 72-77. [CrossRef]

135. Anderson, J.L.; Anderson, C.M.; Chu, J.; Meredith, J.; Asche, F.; Sylvia, G.; Smith, M.D.; Anggraeni, D.; Arthur, R.; Guttormsen, A.; et al. The Fishery Performance Indicators: A Management Tool for Triple Bottom Line Outcomes. PLoS ONE 2015, 10, e0122809. [CrossRef] [PubMed]

136. Van Holt, T.; Weisman, W.; Johnson, J.C.; Käll, S.; Whalen, J.; Spear, B.; Sousa, P. A Social Wellbeing in Fisheries Tool (SWIFT) to Help Improve Fisheries Performance. Sustainability 2016, 8, 667. [CrossRef]

137. Díaz, S.; Pascual, U.; Stenseke, M.; Martín-López, B.; Watson, R.T.; Molnár, Z.; Hill, R.; Chan, K.M.A.; Baste, I.A.; Brauman, K.A.; et al. Assessing nature's contributions to people. Science 2018, 359, 270-272. [CrossRef] [PubMed]

138. Kaplan-Hallam, M.; Bennett, N.J. Adaptive social impact management for conservation and environmental management. Conserv. Biol. 2018, 32, 304-314. [CrossRef]

139. Baum, J.K.; Fuller, S. Canada's Marine Fisheries: Status, Recovery Potential and Pathways to Success; University of Victoria and Oceana Canada: Victoria, BC, Canada, 2016; p. 154.

140. Chandler, P.C.; King, S.A.; Boldt, J.L. State of the Physical, Biological and Selected Fishery Resources of Pacific Canadian Marine Ecosystems in 2017; Fisheries and Oceans Canada, Pacific Biological Station: Nanaimo, BC, Canada, 2018; ISBN 978-0-660-26900-9.

141. Oceana Canada. Fishery Audit 2018: Unlocking Canada's Potential for Abundant Oceans; Oceana Canada: Ottawa, ON, Canada, 2018; p. 20.

142. Gough, J. Managing Canada's Fisheries: From Early Days to the Year 2000; Fisheries and Oceans Canada: Ottawa, ON, Canada, 2007; ISBN 978-2-89448-523-1.

143. Government of Canada. Constitution Act, 1982; Government of Canada: Ottawa, ON, Canada, 1982.

144. Harper, S.; Salomon, A.K.; Newell, D.; Waterfall, P.H.; Brown, K.; Harris, L.M.; Sumaila, U.R. Indigenous women respond to fisheries conflict and catalyze change in governance on Canada's Pacific Coast. Marit. Stud. 2018, 17, 189-198. [CrossRef]

145. Jones, R.; Rigg, C.; Pinkerton, E. Strategies for assertion of conservation and local management rights: A Haida Gwaii herring story. Mar. Policy 2017, 80, 154-167. [CrossRef] 
146. Ecotrust Canada. CATCH-22: Conservation, Communities and the Privatization of B.C. Fisheries; Ecotrust Canada: Vancouver, BC, Canada, 2004; p. 47.

147. Pinkerton, E.; Edwards, D.N. The elephant in the room: The hidden costs of leasing individual transferable fishing quotas. Mar. Policy 2009, 33, 707-713. [CrossRef]

148. Robertson, A.; Sutcliffe, T.; Fernandes, D.; Reid-Kuecks, B.; McIsaac, J.; Nobles, D.; Moriel, L.; Pepper-Smith, K.; Brown, D.; Mesmain, M. Caught Up in Catch Shares; Ecotrust Canada and T. Buck Suzuki Environmental Foundation: Vancouver, BC, Canada, 2014.

149. Standing Committee on Fisheries and Oceans. West Coast Fisheries: Sharing Risks and Benefits; House of Commons Canada: Ottawa, ON, Canada, 2019.

150. Jones, R.; Shepert, M.; Sterritt, N.J. Our place at the table: First Nations in the BC fishery; A Report by the First Nation Panel on Fisheries; First Nation Panel on Fisheries: Vancouver, BC, Canada, 2004.

151. Kearney, J.; Berkes, F.; Charles, A.; Pinkerton, E.; Wiber, M. The Role of Participatory Governance and Community-Based Management in Integrated Coastal and Ocean Management in Canada. Coast. Manag. 2007, 35, 79-104. [CrossRef]

152. Pinkerton, E. Co-Operative Management of Local Fisheries: New Directions for Improved Management and Community Development; UBC Press: Vancouver, BC, Canada, 2011; ISBN 978-0-7748-4308-9.

153. Gill, I. Of Roe, Rights, and Reconciliation. Hakai Magazine, 28 August 2018.

154. Kamat, V.R. Dispossession and disenchantment: The micropolitics of marine conservation in southeastern Tanzania. Mar. Policy 2018, 88, 261-268. [CrossRef]

155. Tauli-Corpuz, V. Report of the Special Rapporteur of the Human Rights Council on the Rights of Indigenous Peoples; United Nations General Assembly: New York, NY, USA, 2016; p. 25.

156. Cooke, B.; Kothari, U. Participation: The New Tyranny? Zed Books: London, UK, 2001; ISBN 978-1-85649-794-797.

157. López-Bao, J.V.; Chapron, G.; Treves, A. The Achilles heel of participatory conservation. Biol. Conserv. 2017, 212, 139-143. [CrossRef]

158. Lang, D.J.; Wiek, A.; Bergmann, M.; Stauffacher, M.; Martens, P.; Moll, P.; Swilling, M.; Thomas, C.J. Transdisciplinary research in sustainability science: Practice, principles, and challenges. Sustain. Sci. 2012, 7, 25-43. [CrossRef]

159. Milkoreit, M. Imaginary politics: Climate change and making the future. Elem. Sci. Anth. 2017, 5, 62. [CrossRef]

160. Pereira, L.; Hichert, T.; Hamann, M.; Preiser, R.; Biggs, R. Using futures methods to create transformative spaces: Visions of a good Anthropocene in southern Africa. Ecol. Soc. 2018, 23, 19. [CrossRef]

161. Tschakert, P.; Oort, B. Van; Clair, A.L.S.; LaMadrid, A. Inequality and transformation analyses: A complementary lens for addressing vulnerability to climate change. Clim. Dev. 2013, 5, 340-350. [CrossRef]

162. Rodríguez, I.; Inturias, M.L. Conflict transformation in indigenous peoples' territories: Doing environmental justice with a "decolonial turn". Dev. Stud. Res. 2018, 5, 90-105. [CrossRef]

163. Marshall, F.; Dolley, J.; Priya, R. Transdisciplinary research as transformative space making for sustainability: Enhancing propoor transformative agency in periurban contexts. Ecol. Soc. 2018, 23, 8. [CrossRef]

164. Charli-Joseph, L.; Siqueiros, J.M.; Eakin, H.; Manuel-Navarrete, D.; Shelton, R. Promoting Agency for Social-Ecological Transformation: A Transformation-Lab in the Xochimilco Social-Ecological System. Ecol. Soc. 2018, 23, 46. [CrossRef]

165. Dyer, M. Transforming communicative spaces: The rhythm of gender in meetings in rural Solomon Islands. Ecol. Soc. 2018, 23, 17. [CrossRef]

166. Moore, M.-L.; Olsson, P.; Nilsson, W.; Rose, L.; Westley, F. Navigating emergence and system reflexivity as key transformative capacities: Experiences from a Global Fellowship program. Ecol. Soc. 2018, 23, 38. [CrossRef]

167. Eakin, H.; York, A.; Aggarwal, R.; Waters, S.; Welch, J.; Rubiños, C.; Smith-Heisters, S.; Bausch, C.; Anderies, J.M. Cognitive and institutional influences on farmers' adaptive capacity: Insights into barriers and opportunities for transformative change in central Arizona. Reg. Environ. Chang. 2016, 16, 801-814. [CrossRef]

(C) 2019 by the authors. Licensee MDPI, Basel, Switzerland. This article is an open access article distributed under the terms and conditions of the Creative Commons Attribution (CC BY) license (http://creativecommons.org/licenses/by/4.0/). 